\title{
PENGEMBANGAN KONSEP SEPEDA PERKOTAAN DENGAN MEMPERTIMBANGKAN KRITERIA ERGONOMI
}

\author{
Bambang Suhardi, Ilham Priadythama dan Muhammad Arief \\ Jurusan Teknik Industri, Universitas Sebelas Maret \\ Jl. Ir. Sutami 36A, Surakarta 57126, Telp/Fax. (0271) 632110 \\ bambangsuhardi_ugm@yahoo.co.id
}

\begin{abstract}
The development of the Indonesian urban bicycle concept requires the most suitable bicycle type as the initial reference which is decided by considering various criteria. Ergonomics is one of the important criteria, considering that the high frequency riding bike which bring health risks, such as CTS, kyphosis and urogenital disorders.

Short wheel base recumbent bike is the most potential for development. The development of this bike includes increased balance by reducing the length of the bike frame and tubing, improve handling by replacing the handlebar is comfortable and uses smaller tires, and use kickstand for easy parking. Besides, the development of this bike adapted to the Indonesian anthropometry and features that support the ability of this bike to explore the city streets.
\end{abstract}

Keywords:urban bikes, ergonomics, development, short wheel base recumbent bike

\section{PENDAHULUAN}

Sepeda merupakan transportasi bertenaga manusia yang ramah lingkungan. Oleh karena itu, dibeberapa kota besar di dunia sepeda telah digunakan sebagai alat transportasi utama atau transportasi penghubung ke transportasi massal. Pemakaian sepeda dengan frekuensi yang tinggi, ternyata menimbulkan gangguan kesehatan, antara lain Carpal Tunnel Syndrome (CTS) pada tangan, kyphosis pada tulang belakang, dan gangguan pada organ kelamin. Oleh karena itu, diperlukan pemilihan tipe sepeda yang dapat meminimumkan timbulnya risiko-risiko tersebut.

Selain risiko kesehatan, infastruktur perkotaan juga merupakan kriteria pemilihan yang perlu diperhatikan.Kota-kota di Indonesia pada umumnya berada di dataran rendah dengan kondisi jalan bervarisasi.Beberapa ruas jalan tidak dilengkapi dengan jalur lambat sehingga dapat memunculkan kebutuhan terhadap sepeda dengan efektivitas pengayuhan tinggi. Disamping itu, kondisi permukaan jalan yang didominasi variasi aspal, paving dan pavement mungkin membutuhkan sepeda dengan kemampuan melewati, baik medan halus dan kasar. Selanjutnya, banyaknya persimpangan dan ramainya kondisi jalan pada dasarnya membutuhkan kemampuan pengendalian yang baik.

Disamping risiko kesehatan dan kondisi infrastruktur perkotaan. Banyaknya tipe sepeda baik yang popular di Indonesia maupun luar negeri dengan karakteristiknya masingmasing merupakan bahan kajian menarik untuk dijadikan referensi dalam pengembangan konsep sepeda yang paling sesuai untuk kondisi perkotaan di Indonesia.

\section{LANDASAN TEORI}

Beberapa penelitian yang terkait dengan sepeda sebagai berikut. Kocabiyik (2004) mengungkapkan secara lengkap mengenai bagaimana melihat suatu produk dengan cara pendekatan konsep desainnya. Kocabiyik melihat pendekatan konsep desain sepeda yang ada di masyarakat saat itu, dimana pembagian jenis sepeda berdasarkan pada kesesuaian dengan konstruksi desain sepeda dan fungsi penggunaan sepeda. Dengan pendekatan desain sepeda secara menyeluruh maka dapat diketahui desain sepeda seperti apa yang dibutuhkan oleh masyarakat saat ini. 
Garnet (2008) membuat rancangan sebuah desain sepeda yang ergonomi. Rancangan desain sepeda dengan memperhatikan berbagai macam posisi pengguna sepeda. Mulai dari posisi tangan, kayuhan sepeda, dan posisi duduk. Tidak hanya sampai perbaikan posisi manusia saja, tetapi juga menganalisis kemampuan membelok dengan mempertimbangkan posisi trail sepeda serta panjang crank guna memaksimalkan kekuatan kayuhan sepeda.

Ginting (2010) membuat pedoman mengenai perancangan produk untuk sepeda. Pengembangan konsep rancangan sepeda mempertimbangkan kriteria-kriteria apa saja yang sedang berkembang di masyarakat pada saat itu.

Rehak (2003) menemukan bahwa pemakaian sepeda yang berlebihan menyebabkan resiko kesehatan pada pemakainya. Pemakai sepeda sering mengalami CTS, karena melakukan aktivitas bersepeda dalam waktu yang lama pada satu posisi tetap. Pada posisi tersebut, getaran dan tekanan berat tubuh beralih ke tangan pengendara yang mengakibatkan otot di bagian tangan terasa kesemutan hingga mati rasa.Apabila hal ini dibiarkan, tangan dapat mengalami penurunan kekuatan dan kemampuan gerak.

Muyor dkk (2011) menyatakan bahwa bersepeda secara berlebihan bisa menyebabkan kyphosis, yaitu kondisi dimana tulang belakang menjadi bungkuk, karena terlalu lama melakukan posisi membungkuk ketika bersepeda. Pengendara sepeda mudah terkena kyphosis karena posisi berkendara sepeda saat ini lebih banyak yang memposisikan pengendara berkendara dengan membungkuk untuk memaksimalkan pengayuhan sepeda.

Bahaya paling mengerikan dari seringnya berkendaran sepeda adalah urogenital disorders. Ilan dan Yoram (2004) mengatakan bahwa posisi duduk sambil mengayuh yang dilakukan dengan frekuensi yang tinggi akan menyebabkan alat kelamin terjepit dan tertekan oleh tubuh. Apabila ini berkelanjutan terus menerus maka akan mengakibatkan alat kelamin mati rasa karena terlalu banyak menopang beban tubuh.

\section{METODOLOGI PENELITIAN}

Metode yang dipakai untuk pengembangan konsep sepeda dibagi menjadi beberapa tahap, yaitu: identifikasi kebutuhan perancangan, penyusunan konsep perancangan, dan pengembangan konsep.

\section{HASIL}

\section{A. Identifikasi Kebutuhan Perancangan}

Informasi yang diperoleh untuk mengidentifikasi kebutuhan perancangan bersumber pada buku, artikel, jurnal ilmiah, dan internet yang berhubungan dengan sepeda. Baik dari segi desain sepeda, fungsi sepeda, komponen sepeda hingga resiko kesehatan yang disebabkan oleh aktifitas bersepeda. Identifikasi kebutuhan perancangan dibuat untuk menjelaskan batasan-batasan masalah dalam pembuatan konsep perancangan dan mempermudah tahapan penyelesaian yang harus dilakukan sehingga sepeda yang akan dirancang sesuai dengan tujuan. Terdapat 74 kriteria yang diperoleh dari hasil identifikasi literatur tersebut.

\section{B. Penyusunan Konsep Perancangan}

Kriteria yang telah diperoleh dari studi literatur sebelumnya, kemudian ditinjau ulang oleh tim peneliti sepeda. Kriteria dilihat tingkat relevansinya dan kriteria diredudansi dengan cara mengabungkan kriteria yang hampir sama menjadi satu. Setelah dilakukan redudansi dan relevansi, dari 74 kriteria menjadi 20 kriteria.

Konfirmasi kriteria yang telah dibuat dilakukan oleh beberapa pihak yang expert mengenai sepeda. Terdapat 4 kategori responden yaitu pengguna sepeda, teknisi sepeda, akademisi mengenai sepeda, dan tim peneliti sepeda. Skala penilaian dibagi menjadi 3 skala yaitu: tidak penting, agak penting dan sangat penting. Total responden yang diambil adalah 8 orang. Setelah dinilai, kemudian ditotal penilaian seluruh responden dan dicari nilai rata-rata perkriteria. Setelah itu dicari nilai natural cut off point. Kriteria yang 
memiliki rata-rata dibawah nilai natural cut off point dibuang dari kriteria awal. Sehingga terpilih 13 kriteria sepeda.

Tabel 1. Kriteria sepeda

\begin{tabular}{|r|l|}
\hline No & \multicolumn{1}{|c|}{ Kriteria } \\
\hline 1 & Frame \\
\hline 2 & fungsi utama sepeda \\
\hline 3 & keawetan sepeda \\
\hline 4 & keseimbangan sepeda \\
\hline 5 & kemampuan membelok \\
\hline 6 & ketangguhan sepeda \\
\hline 7 & estetika rangka \\
\hline 8 & Safety \\
\hline 9 & mudah diparkirkan \\
\hline 10 & aktifitas mengayuh \\
\hline 11 & postur tubuh pengguna \\
\hline 12 & kenyamanan berkendara \\
\hline 13 & menghindari risiko kesehatan \\
\hline
\end{tabular}

Setelah mendapatkan kriteria dan bobot kriteria sepeda. Langkah selanjutnya adalah mencari alternatif konsep. Berdasarkan studi pendahuluan dan penelusuran jenisjenis sepeda yang ada di Indonesia, yaitu menurut Kocabiyik (2004), McGoldrick (2009), dan Fairuz (2009) terdapat 17 alternatif konsep sepeda untuk daerah perkotaan. Mulai dari sepeda yang berjenis road bike, mountain bike, BMX, hybrid, roadster, recumbent dan style. Sepeda tersebut memiliki perbedaan di bagian komponen, fungsi, cara mengendarai dan posisi mengendarainya. Penilaian konsep dilakukan dengan cara membandingkan konsep yang ada dengan kriteria yang telah didapat sebelumnya. Penilaian konsep melalui cara Internal Focus Group Discussion untuk dapat menilai dan memutuskan konsep rancangan sepeda yang akan digunakan di daerah perkotaan Indonesia. Hasil penilaian serta pembobotan konsep ditunjukkan pada tabel 2.

\section{Pengembangan Konsep Perancangan}

Dari penilaian tersebut terpilih 3 konsep sepeda yang memiliki nilai kriteria tertinggi yaitu modern roadster, MTB 27”, dan short wheel base recumbent bike. Untuk konsep sepeda yang terpilih, setiap kriteria yang memiliki potensi untuk dikembangkan akan diberi perbaikan dengan tujuan agar nilai pada kriteria tersebut dapat naik sehingga menjadi konsep sepeda terbaik. Tabel 3, 4, dan 5 menunjukkan analisis pengembangan dari kriteria konsep sepeda tersebut. 
Tabel 2. Hasil pembobotan kriteria

\begin{tabular}{|c|c|c|c|c|c|c|c|c|c|c|c|c|c|c|c|c|c|c|}
\hline & 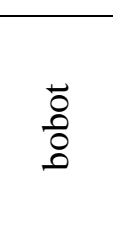 & $\underset{\overparen{Z}}{\mathscr{Z}}$ & 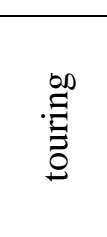 & 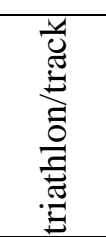 & 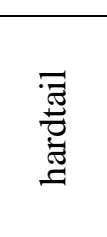 & 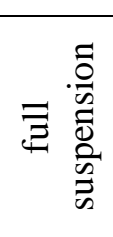 & 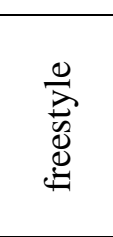 & 突 & 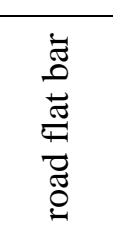 & $\begin{array}{l}\overline{\bar{N}} \\
\stackrel{n}{E} \\
\sum\end{array}$ & $\begin{array}{l}\cdot \frac{U}{N} \\
\tilde{D} \\
\frac{\pi}{0} \\
\frac{\overrightarrow{0}}{0}\end{array}$ & $\begin{array}{l}\stackrel{\infty}{\Xi} \\
\stackrel{\sigma}{0} \\
\stackrel{0}{O}\end{array}$ & 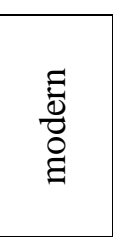 & 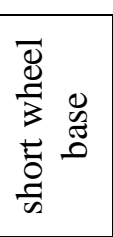 & 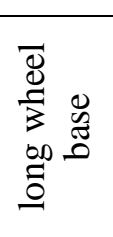 & : & 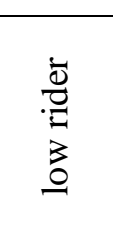 & 离 \\
\hline frame & 0.0748 & 0.1497 & 0.1497 & 0.0748 & 0.1497 & 0.0748 & 0.1497 & 0.1497 & 0.1497 & 0.1497 & 0.0748 & 0.2245 & 0.1497 & 0.2245 & 0.2245 & 0.1497 & 0.0748 & 0.0748 \\
\hline $\begin{array}{l}\text { fungsi utama } \\
\text { sepeda }\end{array}$ & 0.0816 & 0.0816 & 0.1633 & 0.0816 & 0.1633 & 0.0816 & 0.1633 & 0.0816 & 0.2449 & 0.2449 & 0.1633 & 0.2449 & 0.2449 & 0.2449 & 0.1633 & 0.1633 & 0.0816 & 0.1633 \\
\hline keawetan sepeda & 0.0714 & 0.0714 & 0.1429 & 0.0714 & 0.2143 & 0.2143 & 0.2143 & 0.2143 & 0.1429 & 0.2143 & 0.2143 & 0.0714 & 0.1429 & 0.1429 & 0.1429 & 0.1429 & 0.1429 & 0.1429 \\
\hline $\begin{array}{l}\text { keseimbangan } \\
\text { sepeda }\end{array}$ & 0.0782 & 0.0782 & 0.1565 & 0.0782 & 0.1565 & 0.2347 & 0.2347 & 0.2347 & 0.1565 & 0.2347 & 0.0782 & 0.1565 & 0.2347 & 0.1565 & 0.2347 & 0.0782 & 0.2347 & 0.2347 \\
\hline $\begin{array}{l}\text { kemampuan } \\
\text { membelok }\end{array}$ & 0.0782 & 0.1565 & 0.1565 & 0.0782 & 0.2347 & 0.2347 & 0.2347 & 0.2347 & 0.2347 & 0.2347 & 0.1565 & 0.2347 & 0.2347 & 0.1565 & 0.0782 & 0.1565 & 0.0782 & 0.2347 \\
\hline $\begin{array}{l}\text { ketangguhan } \\
\text { sepeda }\end{array}$ & 0.0714 & 0.0714 & 0.1429 & 0.0714 & 0.2143 & 0.1429 & 0.2143 & 0.2143 & 0.1429 & 0.2143 & 0.1429 & 0.0714 & 0.2143 & 0.1429 & 0.0714 & 0.0714 & 0.1429 & 0.2143 \\
\hline estetika rangka & 0.0714 & 0.2143 & 0.1429 & 0.2143 & 0.2143 & 0.2143 & 0.0714 & 0.0714 & 0.2143 & 0.2143 & 0.2143 & 0.2143 & 0.1429 & 0.2143 & 0.2143 & 0.2143 & 0.2143 & 0.1429 \\
\hline safety & 0.0816 & 0.0816 & 0.1633 & 0.0816 & 0.2449 & 0.1633 & 0.2449 & 0.2449 & 0.1633 & 0.2449 & 0.1633 & 0.1633 & 0.2449 & 0.2449 & 0.2449 & 0.0816 & 0.2449 & 0.2449 \\
\hline $\begin{array}{l}\text { mudah } \\
\text { diparkirkan }\end{array}$ & 0.0714 & 0.0714 & 0.2143 & 0.0714 & 0.1429 & 0.0714 & 0.1429 & 0.1429 & 0.1429 & 0.1429 & 0.2143 & 0.2143 & 0.2143 & 0.0714 & 0.0714 & 0.0714 & 0.2143 & 0.2143 \\
\hline $\begin{array}{l}\text { aktifitas } \\
\text { mengayuh }\end{array}$ & 0.0748 & 0.2245 & 0.2245 & 0.2245 & 0.1497 & 0.0748 & 0.0748 & 0.0748 & 0.2245 & 0.1497 & 0.0748 & 0.1497 & 0.1497 & 0.2245 & 0.1497 & 0.1497 & 0.0748 & 0.1497 \\
\hline $\begin{array}{l}\text { postur tubuh } \\
\text { pengguna }\end{array}$ & 0.0816 & 0.0816 & 0.0816 & 0.0816 & 0.1633 & 0.1633 & 0.2449 & 0.2449 & 0.0816 & 0.1633 & 0.2449 & 0.1633 & 0.2449 & 0.2449 & 0.2449 & 0.0816 & 0.0816 & 0.2449 \\
\hline $\begin{array}{l}\text { kenyamanan } \\
\text { berkendara }\end{array}$ & 0.0816 & 0.0816 & 0.1633 & 0.0816 & 0.2449 & 0.2449 & 0.1633 & 0.1633 & 0.0816 & 0.2449 & 0.1633 & 0.0816 & 0.1633 & 0.2449 & 0.2449 & 0.0816 & 0.1633 & 0.2449 \\
\hline $\begin{array}{l}\text { menghindari } \\
\text { risiko kesehatan }\end{array}$ & 0.0816 & 0.0816 & 0.0816 & 0.0816 & 0.1633 & 0.1633 & 0.1633 & 0.1633 & 0.0816 & 0.1633 & 0.1633 & 0.0816 & 0.2449 & 0.2449 & 0.2449 & 0.0816 & 0.0816 & 0.2449 \\
\hline total & 1 & 1.4456 & 1.9830 & 1.2925 & 2.4558 & 2.0782 & 2.3163 & 2.2347 & 2.0612 & 2.6156 & 2.0680 & 2.0714 & 2.6259 & 2.5578 & 2.3299 & 1.5238 & 1.8299 & 2.5510 \\
\hline
\end{tabular}


Tabel 3. Analisis pengembangan kriteria MTB 27”

\begin{tabular}{|l|l|}
\hline \multicolumn{1}{|c|}{ Kriteria } & \multicolumn{1}{c|}{ Analisis Pengembangan } \\
\hline frame & Frame bisa dirubah tetapi akan membuat rangka tidak simpel \\
\hline mudah diparkirkan & Tidak dapat dikembangkan karena awalnya tidak memiliki tuas standar \\
\hline aktifitas mengayuh & $\begin{array}{l}\text { Bisa dikembangkan dengan mengubah lingkar roda menjadi lebih besar } \\
\text { tetapi akan mengurangi keseimbangan sepeda dan kemampuan } \\
\text { membelok sepeda. }\end{array}$ \\
\hline postur tubuh pengguna & Tidak dapat dikembangkan karena postur right-up tidak bisa diubah \\
\hline $\begin{array}{l}\text { menghindari risiko } \\
\text { kesehatan }\end{array}$ & $\begin{array}{l}\text { Dapat dikembangkan dengan mengganti handlegrip dan sedel sepeda } \\
\text { yang lebih lembut }\end{array}$ \\
\hline
\end{tabular}

Tabel 4. Analisis pengembangan kriteria modern roadster

\begin{tabular}{|l|l|}
\hline \multicolumn{1}{|c|}{ Kriteria } & \multicolumn{1}{c|}{ Analisis Pengembangan } \\
\hline Frame & Frame bisa dirubah tetapi akan membuat rangka tidak simpel \\
\hline keawetan sepeda & Tidak dapat dikembangkan karena tidak ada yang bisa diganti \\
\hline estetika rangka & Tidak dapat dikembangkan karena tidak bisa diubah \\
\hline aktifitas mengayuh & Dapat dikembangkan dengan mengganti lingkar roda yang lebih besar \\
\hline kenyamanan berkendara & Dapat dikembangkan dengan memberi suspensi pada fork sepeda \\
\hline
\end{tabular}

Tabel 5. Analisis pengembangan kriteria short wheel base

\begin{tabular}{|l|l|}
\hline \multicolumn{1}{|c|}{ Kriteria } & \multicolumn{1}{c|}{ Analisis Pengembangan } \\
\hline keawetan sepeda & Tidak dapat dikembangkan karena tidak ada yang bisa diganti \\
\hline keseimbangan sepeda & $\begin{array}{l}\text { Dapat dikembangkan dengan mengatur ulang ketinggian sepeda dan } \\
\text { posisi tube sesuai dengan antropometri }\end{array}$ \\
\hline kemampuan membelok & Dapat dikembangkan dengan mengubah posisi handlebar \\
\hline ketangguhan sepeda & Tidak dapat dikembangkan karena tidak ada yang bisa diganti \\
\hline mudah diparkirkan & Dapat dikembangkan dengan memberi tuas penyangga \\
\hline
\end{tabular}

Nilai dari hasil analisis dibandingkan kembali antara 3 sepeda tersebut, sepeda yang memiliki nilai tertinggi yang akan diambil sebagai konsep sepeda terbaik untuk perkotaan di Indonesia. Berikut hasil penilaian dan pembobotannya. Nilai dari hasil analisis dibandingkan kembali antara 3 sepeda tersebut. Sepeda yang memiliki nilai tertinggi lah yang akan diambil sebagai konsep terbaik dan short wheel base recumbent bike terpilih menjadi konsep desain sepeda terbaik dengan nilai 2,78571. Setelah dipilih konsep sepeda terbaik maka perlu adanya spesifikasi fitur yang menunjang sepeda ini sebagai sepeda perkotaan. Fitur-fitur yang dipilih adalah sebagai berikut.

a. Tempat duduk, ukuran tempat duduk disesuaikan dengan antropometri ukuran tubuh orang Indonesia, sehingga nyaman saat dikendarai.

b. Frame, ukuran frame disesuakan dengan jangkauan kaki orang Indonesia sehingga memudahkan pengendara saat mengayuh sepeda.

c. Handlebar, bentuk handlebar menggunakan bentuk W sehingga tangan mudah dalam menggengam handle serta tidak mengganggu saat mengayuh pedal. Karena menggunakan handlebar ini maka untuk tuas rem menggunakan tipe reverse brake yang sesuai dengan posisi tangan.

d. Tuas penyangga, untuk mempermudah pengendara memarkirkan sepeda.

e. Roda, ukuran roda depan 20" agar memudahkan kendali sepeda dan roda belakang 27" untuk menahan berat tubuh dan memaksimalkan efek pengayuhan. 
f. Drive train menggunakan internal hub gear. Dengan menggunakan internal hub gear maka dapat meminimalkan panjang rantai. Internal hub gear juga memiliki ratio yang besar sehingga cocok ntuk daerah perkotaan. Penggunaan bashguard dan chainguard untuk melindungi rantai

g. Brake system menggunakan rem cakram untuk roda depan dan V-brake untuk roda bagian belakang.

Berikut visualisasi konsep dengan fitur yang telah dikembangkan.
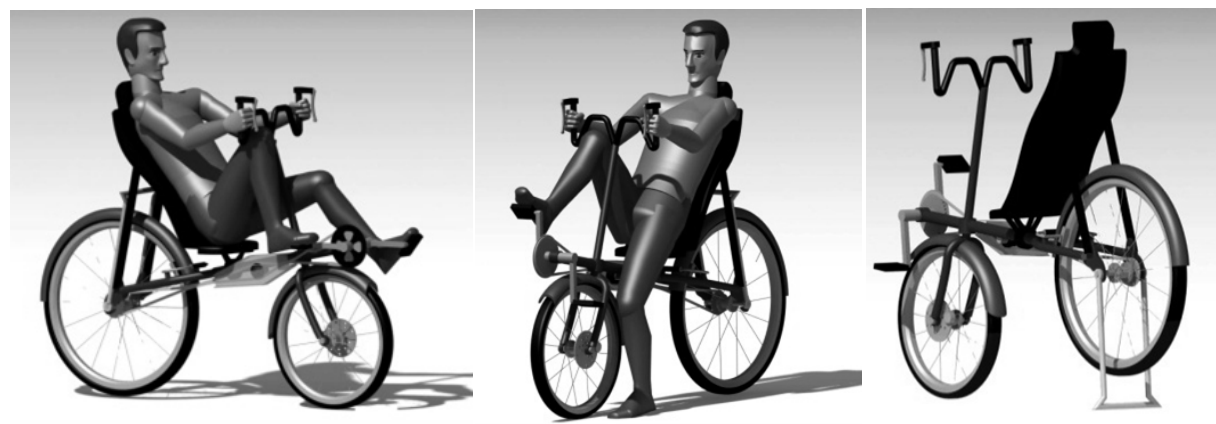

Gambar 1 Visualisasi Konsep Hasil Rancangan

\section{PEMBAHASAN}

\section{A. Analisis Identifikasi Kebutuhan Perancangan}

Dari hasil pengamatan diperoleh bahwa banyak penggunaan sepeda yang salah, yaitu penggunaan jenis sepeda yang kurang cocok digunakan untuk daerah perkotaan.Hal ini dikarenakan faktor ketersediaan dan trend yang ada di masyarakat untuk bergaya dan kurang didasarkan pada fungsi, serta pertimbangan risiko kesehatan. Penggunaan sepeda yang kurang tepat dan frekuensi yang tinggi (overuse) akan mengakibatkan beberapa risiko kesehatan pada tubuh pengguna sepeda. Untuk itu perlu adanya suatu konsep sepeda perkotaan yang dapat menghindari risiko kesehatan bagi pengguna sepeda dan memperhatikan kriteria-kriteria lainnya yang mempengaruhi rancangan sepeda tersebut.

\section{B. Analisis Penyusunan Konsep Perancangan}

Kriteria awal yang diperoleh dari dokumentasi dan observasi adalah 74 kriteria. Setelah itu kriteria tersebut diredudansi dan direlevansi sehingga kriteria berkurang menjadi 20 kriteria. Ke-20 kriteria tersebut kemudian dikonfirmasi kembali oleh responden yang merupakan ahli di bidang sepeda. Melalui konfirmasi ini kriteria yang berjumlah 20 menjadi 13 kriteria. Ke-13 kriteria ini merupakan kriteria sepeda perkotaan. Setelah memperoleh kriteria sepeda perkotaan, langkah selanjutnya adalah proses pembangkitan alternatif. Ada sekitar 17 alternatif konsep sepeda perkotaan. Setelah itu dilakukan penilaian konsep berdasarkan kriteria-kriteria tersebut melalui Internal Focus Group Disscussion. Hasil penilaian konsep menghasilkan 3 konsep sepeda perkotaan yaitu modern roadster, MTB 27”, dan short wheel base.

\section{Análisis Pengembangan Konsep Sepeda Perkotaan}

Setelah dipilih beberapa alternatif konsep sepeda yang didapat pada penilaian sebelumnya, 3 konsep sepeda tersebut dikembangkan menurut kriteria yang masih dapat potensial untuk ditingkatkan. Sehingga nilai dari kriteria tersebut dapat naik dan menjadi konsep yang terbaik. Pada MTB 27" kriteria yang masih dapat dikembangkan adalah kriteria aktifitas mengayuh dengan mengganti lingkar roda menjadi lebih besar dan menghindari risiko kesehatan dengan mengganti sadel dan handlegrip. Pada modern roadster kriteria yang dapat dikembangkan adalah kriteria aktifitas mengayuh dengan mengganti lingkar roda menjadi lebih besar dan kenyamanan berkendara dengan 
menambahkan suspensi. Sedangkan pada short wheel base yang dapat dikembangkan adalah kriteria keseimbangan sepeda dengan mengatur ulang ketinggian sepeda dan posisi tube, kemampuan membelok dengan mengganti handlebar serta mengganti roda depan dengan lingkar roda lebih kecil, untuk kemudahan untuk parkir dengan memberi tuas penyangga.Kemudian dinilai dengan nilai pembobotan per kriteria sehingga diperoleh bahwa konsep sepeda yang cocok untuk daerah perkotaan di Indonesia adalah short wheel base recumbent bike.

\section{Analisis Pengembangan Short Wheel Base Recumbent Bike}

Penilaian postur tubuh dengan membandingkan antar posisi upright dan recumbent. Penilaian yang digunakan adalah Rapid Entire Body Assessment (REBA). REBA dipilih karena dapat menganalisis postur tubuh pengendara baik itu bagian atas maupun bagian bawah. Posisi yang diambil adalah posisi saat kayuhan maksimum. Posisi berkendara yang dibandingkan antara posisi berkendara short wheel base (SWB) recumbent bike sebagai konsep sepeda terpilih dengan MTB 27" karena dinilai memiliki posisi ternyaman dengan posisi upright.Dari segi posisi kepala, pengendara MTB 27" memposisikan kepalanya menunduk kebawah sedangkan pengendara SWB tegak ke depan. Dari segi posisi punggung sangat terlihat bahwa pengendara MTB 27" sangat membungkuk, sedangkan pengendara SWB karena merebah maka punggung dalam posisi lurus sehingga dapat mengendarai dengan lebih santai dalam waktu lama. Untuk posisi kaki tangan, pengendara SWB juga memiliki posisi yang santai karena tangan tidak menumpu berat tubuh seperti pengendara MTB 27”. Sedangkan untuk posisi kaki MTB 27” dinilai lebih baik karena kaki lebih lurus dalam mengayuh tidak seperti SWB yang memiliki postur kaki yang lebih menekuk, tetapi ini dapat diatasi dengan cara memperpanjang jarak bottom brake sehingga kaki dapat lebih santai dalam mengayuh karena sudut tekukan lutut menjadi lebih besar. Untuk sepeda dengan posisi berkendara MTB 27"memiliki nilai 10 yang artinya postur tersebut sangat berbahaya. Sedangkan pada recumbent memiliki nilai 4 yang artinya cukup berbahaya. Akan tetapi nilai ini hanya dari segi postur saja, penyangga tubuh tidak perhitungkan pada penilaian REBA.

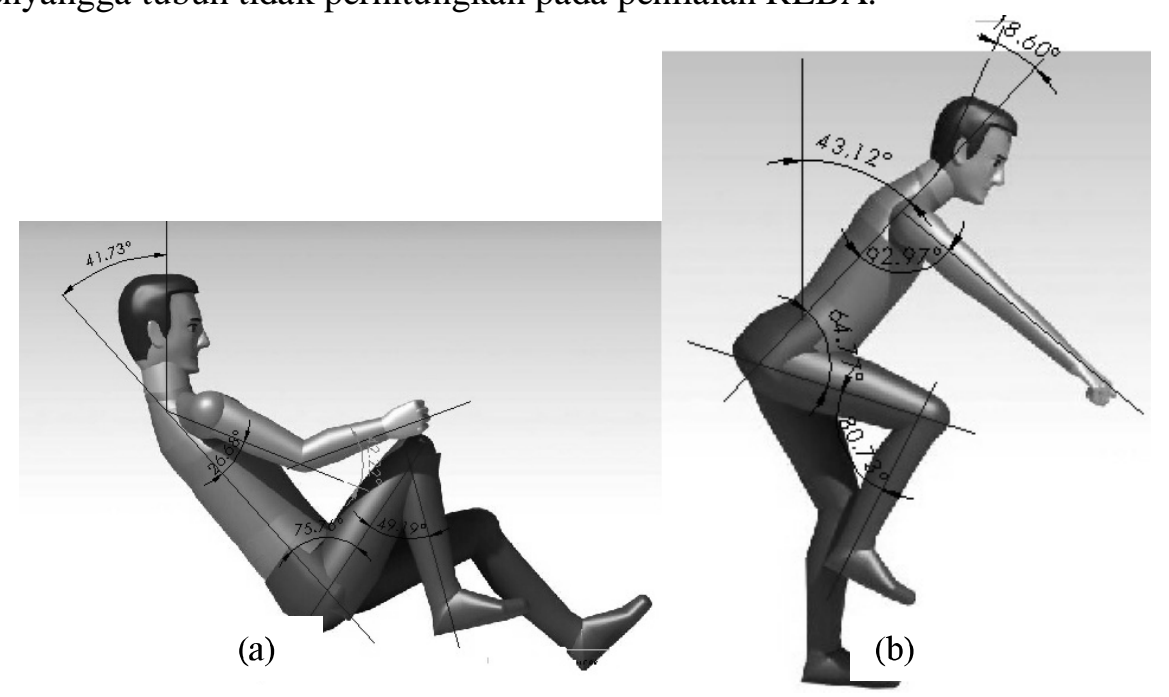

Gambar 2(a) Posisi berkendara SWB recumbent bike

(b) Posisi berkendara MTB 27”

Selain posisi tubuh yang lebih santai, jarak pandang pun dinilai lebih bagus.SWB recumbent bike memiliki jarak pandang yang lebih jauh dari pada upright. Ini disebabkan posisi duduk recumbent yang memposisikan kepala sejajar arah pandang sehingga mata dapat leluasa melihat lurus ke depan dan hanya terhalang oleh lutut kaki karena kegiatan mengayuh. Sedangkan posisi MTB 27” memiliki jarak pandang yang kurang leluasa 
karena posisi kepala menunduk ke bawah sehingga mata tertuju ke bawah pula dan untuk melihat ke depan, pengendara harus sedikit melirik ke atas.

Selain sebagai alat transportasi perkotaan, sepeda juga harus dapat membawa barang bawaan pengendara. Dari segi konstruksinya, modern roadster memiliki tempat membawa barang yang potensial pada bagian depan dan belakang. Pada bagian depan (1a) beban yang dibawa tergolong beban ringan, sedangkan untuk bagian belakangnya (2a) dapat membawa beban yang berat. Untuk SWB, lokasi yang potensial untuk membawa barang adalah bagian belakang dan bawah rangka. Untuk membawa beban ringan dapat menggunakan bagian belakang sepeda.Sedangkan untuk beban yang berat, beban dapat ditempatkan pada bawah sepeda, Tetapi karena sepeda ini digunakan untuk daerah perkotaan maka kemampuan untuk membawa beban yang banyak tidak terlalu diutamakan. Rata-rata orang di daerah kota hanya membawa beban yang tidak berlebih.

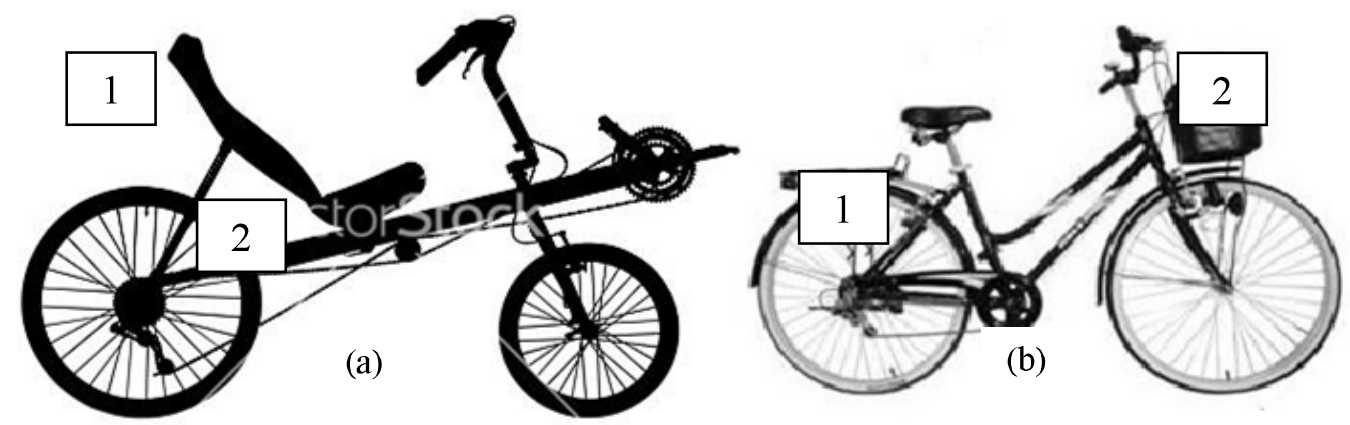

Gambar 3 (a)Lokasi potensial untuk pengangkutan SWB

(b) Lokasi potensial untuk pengangkutan modern roadster

Perancangan sepeda ini ditujukan untuk pengguna pria dewasa. Bagi pengguna wanita, perlu ditambahkan fairing yang berfungsi sebagai penutup pada bagian depan saat mengayuh sepeda. Selain itu fairing juga berfungsi untuk mengurangi tekanan aliran udara sehingga meningkatkan aerodinamis SWB recumbent bike. Untuk penggunaan sepeda di malam hari, perlu adanya pemasangan lampu baik pada bagian depan maupun belakang sepeda. Ini bertujuan agar menambah tingkat penglihatan pengendara saat malam hari.Dan juga untuk mengikuti perkembangan sepeda maka sepeda ini bisa juga menjadi sepeda listrik.Teknologi sepeda listrik sekarang sudah berkembang.Untuk merubah sepeda manual menjadi sepeda listrik sangat mudah. Pengendara tinggal memasang motor listrik pada bagian roda belakang. Bentuk dari motor ini sendiri seperti tromol sepeda motor.

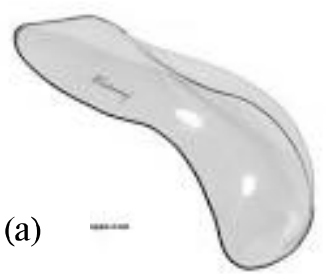

Gambar 4(a) fairing, (b) lampu sepeda dan (c) motor sepeda 


\section{KESIMPULAN DAN SARAN}

\section{A. Kesimpulan}

Berdasarkan hasil penelitian yang dilakukan dapat ditarik kesimpulan yang mengacu pada pada tujuan sebagai berikut.

1. Kriteria-kriteria sepeda untuk penggunaan sepeda di Indonesia ada 13 yaitu frame, fungsi utama sepeda, keawetan sepeda, keseimbangan sepeda, kemampuan membelok, ketangguhan sepeda, estetika rangka, safety, mudah diparkirkan, aktifitas mengayuh, postur tubuh pengguna, kenyamanan berkendara dan menghindari risiko kesehatan.

2. Penelitian ini memilih short wheel base recumbent bike sebagai konsep sepeda perkotaan di Indonesia yang sesuai dengan kriteria-kriteria sepeda perkotaan dan menghindari risiko kesehatan. Short wheel base recumbent bike dapat dikembangkan dari segi keseimbangan dengan mengatur ulang ketinggian sepeda, kemampuan membelok dengan mengganti handlebar serta mengganti ban depan dengan lingkar ban lebih kecil, untuk kemudahan parkir dengan menambah tuas penyangga untuk parkir.

3. Fitur yang digunakan untuk short wheel base recumbent bike untuk daerah perkotaan di Indonesia adalah tempat dudukyang telah disesuaikan dengan ukuran tubuh orang Indonesia, ukuran frame yang telah disesuakan dengan jangkauan kaki orang Indonesia, handlebar dengan bentuk $\mathrm{W}$ dan reverse brake yang sesuai dengan posisi tangan, tuas penyangga untuk kemudahan parkir, ukuran roda depan 20" dan roda belakang 27”, drive train menggunakan internal hub gear, penggunaan bashguard dan chainguard untuk melindungi rantai, dan brake system menggunakan rem cakram dan V-brake.

\section{B. Saran}

Saran yang diberikan untuk penelitian selanjutnya adalah perlu adanya kajian dari segi biomekanika sehingga dapat diketahui secara detail bagaimana daya kayuhan sepeda tersebut. Disamping itu juga, Perlu adanya spesfikasi sepeda secara detail sehingga dapat dibuat prototype-nya.

\section{DAFTAR PUSTAKA}

[1] Epema, H.K., Brand, S., Gregoor, Wouter., Kooijman, J.D.G., Pereboom, H.P., Wielemaker, D.C., Zweep, C.J., 2012, Bicycle Design: A Different Approach To Improving On The World Human Powered Speed Records, Procedia Engineering 34, hal 313-318

[2] Fairuz, 2011, Bike To Work Polygon Heist 1.0 Sepeda Hibrid Harga Terjangkau,http://fairuzelsaid.wordpress.com/2011/03/27/bike-to-work-polygonheist-1-0-sepeda-hibrid-harga-terjangkau. Diakses pada tanggal 19 September 2013

[3] Filingeri, D., Jemni, M., Bianco, A., 2012. The Effect of Vibration During Maximal Graded Cycling Exercise: A Pilot Study, Journal of Sport Science and Medicine 11, hal.423-429.

[4] Fishman, E., Washington, S., Haworth, N., 2012, Barriers and Facilitator to Public Bicycle Scheme Use: A Qualitative Approach, Transportation Research Part F 15 hal.686-698.

[5] Garnet, M. Garnet., 2008, Ergonomics of Direct-Drive Recumbent Bicycle, Ottawa: ON, Canada.

[6] Ginting, Rosnani., 2010, Perancangan Produk, Graha Ilmu, Yogyakarta

[7] Gregor, Scott, M., Perell, Karena L., Rushatankovit, S., Miyamoto, E., Muffoletto, R., Gregor, R.J., 2002, Lower Extremity General Muscle Moment Patterns in Healthy Inividuals During Recumbent Cycling, Clinic Biomechanics 17, hal.123- 
129.

[8] Hutson, Warren., 2010, Cycling Injuries-Prevention and Treatment, SIRC

[9] Kocabiyik, Elif., 2004, Engineering Concepts in Industrial Product Design With A Case Study of Bicycle Design, Izmir Institute of Technology, Turki

[10] Kristanto, Yuke I., 2010, Desain Sepeda Untuk Lanjut Usia, Tugas Akhir Jurusan Desain Produk, ITS, Surabaya

[11] Leibovitch, Ilan., Mor, Yoram., 2005, The Vicious Cycling: Bicycling Related Urogenital Disorders, European Urology, 47, hal 277-287.

[12] McGoldrick, Michael., 2009, Choosing the Right Bike For You. http://gobiking.ca/which-bike/. Diakses pada tanggal 1 September 2013

[13] Muyor, Jose. M., Minarro, Pedro., A. Lopez, and Alacid, Fernando., 2011, Spinal Posture of Thoracic and Lumbar Spine and Pelvic Tilt in Highly Trained Cyclist, Journal of Sports Science and Medicine, 10, hal.355-361 